\title{
François Zufferey, Pierre de Saint-Cloud, trouvère normand
}

Maria Colombo Timelli

\section{(2) OpenEdition}

1 Journals

Édition électronique

URL : https://journals.openedition.org/studifrancesi/2978

DOI : 10.4000/studifrancesi.2978

ISSN : 2427-5856

Éditeur

Rosenberg \& Sellier

Édition imprimée

Date de publication : 1 juillet 2013

Pagination : 427

ISSN : 0039-2944

\section{Référence électronique}

Maria Colombo Timelli, «François Zufferey, Pierre de Saint-Cloud, trouvère normand », Studi Francesi [En ligne], 170 (LVII | II) | 2013, mis en ligne le 30 novembre 2015, consulté le 02 février 2023. URL : http:// journals.openedition.org/studifrancesi/2978; DOI : https://doi.org/10.4000/studifrancesi.2978

Ce document a été généré automatiquement le 2 février 2023.

\section{cc) (†)}

Creative Commons - Attribution - Pas d'Utilisation Commerciale - Pas de Modification 4.0 International - CC BY-NC-ND 4.0

https://creativecommons.org/licenses/by-nc-nd/4.0/ 


\title{
François Zufferey, Pierre de Saint- Cloud, trouvère normand
}

\author{
Maria Colombo Timelli
}

\section{RÉFÉRENCE}

FRANÇOIS ZUFFEREY, Pierre de Saint-Cloud, trouvère normand, in «Romania», 130, 2012, pp. 1-39.

Ce long article a pour but de restituer à Pierre de Saint-Cloud ce qui, aux yeux de F.Z., lui revient: origine normande (à l'encontre de l'opinion de Gaston Paris, qui le croyait parisien), participation à la rédaction du Roman d'Alexandre dodécasyllabique (seconde partie de la branche IV), paternité du tronc primitif du Roman de Renard. L'analyse menée par F.Z., basée sur des éléments linguistiques - scripta, morphologie, lexique, style - et qu'il est impossible de résumer en quelques lignes, tient compte également de la tradition textuelle des œuvres en question, et donc des éléments codicologiques, ainsi que du contexte culturel et politique de la fin du XII ${ }^{\mathrm{e}}$ siècle. 